\title{
Computer-Aided System for Monitoring and Planning of Actions to Increase Machine-Building Enterprises Energy Efficiency
}

\author{
Nataliya Stupnytska* \\ Lviv Polytechnic National University, 12, S. Bandery St., Lviv, 79013, Ukraine
}

Received: April 08, 2019. Revised: April 18, 2019. Accepted: May 20, 2019.

(C) 2019 The Author. Published by Lviv Polytechnic National University.

\begin{abstract}
The article describes mathematical model of analyses the energy use costs efficiency (depending on the type and volume of products produced by the machine-building enterprise, the consumption of certain types of energy resources and their use in specific production processes, etc.). Methodology and mathematical model of the plan for modernization of industrial production energy-consuming processes has been developed. Estimation of energy saving actions efficiency is proposed by calculation of the ratio of energy consumption cost reduction to the cost of installation works and materials related with the implementation of these actions. The article outlines problem-oriented classification of energyconsuming machine-building production processes and actions intended to reduce the specific energy machine-building enterprise consumption. The algorithm and program realization of the computer-aided system for monitoring and planning of actions to increase machine-building enterprises energy efficiency are proposed.
\end{abstract}

Keywords: mathematical model; energy efficiency monitoring; enterprise; energy saving.

\section{Introduction}

The concept of the Energy Strategy of Ukraine's Development for the period to 2035 "Safety, Energy Efficiency, Competitiveness", defines the problem of energy efficiency as a strategically important [1]. The problems of low energy efficiency of machine building production are connected, first of all, with inefficient use of fuel and energy resources (FER), loss of coal mining capacities in the occupied territories of the Donbas, unfavorable macroeconomic situation in the state. The cost of energy in Ukraine is rapidly increasing as a result of shortage of own energy resources, a lack of sufficient alternative energy sources and problems with the procurement of energy from non-residents [2]. The inefficient use of fuel and energy resources together with the increase in the cost of energy carriers leads to an increase in production costs, which is negatively affects reduction in the competitiveness of machine-building enterprises.

Ukraine is one of the most inefficient energy consumers among the industrial countries of Europe [2]. The reasons for this are outdated and inefficient energy-intensive technologies and worn-out means of engineering, as well as low thermal insulation of buildings and outdated heat generation equipment. The specific energy intensity of Ukrainian products, defined as the ratio of the total consumption of all types of energy to Gross National Product (GNP), is about 4.8 times more than in the UK, 3.8 times higher than in Turkey, 3 times more than in Poland and even at 1.8 times more than in Belarus. As to the average value for the European Union, the energy intensity of Ukraine's products is 3.8 times higher and 2 times higher than the average value for the world! Ukraine annually loses billions US $\$$ because of excessive energy costs [2].

The global trend of diminishing energy costs, especially in engineering, is a priority. According to the Paris Agreement, the member states of the International Energy Agency (IEA) require substantial redistribution of capital

\footnotetext{
* Corresponding author. Email address: stupn@i.ua
}

This paper should be cited as: N. Stupnytska. Computer-aided system for monitoring and planning of actions to increase machine-building enterprises energy efficiency. Energy Engineering and Control Systems, 2019, Vol. 5, No. 1, pp. 39 - 46. https://doi.org/10.23939/jeecs2019.01.039 
sent to the energy sector [3]. The distribution of total investment in energy supply in excess of $\$ 40$ trillion is transferred from non-renewable sources to renewable energy sources: nuclear, solar and wind power. It is planned that by 2040 the share of extractive fuel should decrease to 30\%. In addition, according to the IEA's "Efficient World Scenario" [13] recommendations, to invest in a less energy-intensive economy in the period up to 2035, more than \$ 11.8 trillion should be invested. These investments are partly offset by an increase in production volumes by $\$ 18$ trillion. Only in the engineering industry total additional energy-saving investments will be more than $\$ 300$ billion. The US, according to IEA forecasts, will reduce electricity demand by about $20 \%$ by 2040 by about $8 \%$, and will reduce energy investment by $\$ 450$ billion [3]. The profits generated by the growth of energy efficiency of industrial enterprises are already about $\$ 540$ billion, primarily in the construction and engineering industry.

Most structured energy management services departments operate in most developed industrial enterprises in Europe and the United States. Such management system allows determining the most effective ways for substantially increase energy efficiency. Among the developed countries, the United States, was the first in the implementation and structuring of energy management - the ANSI / MSE 2000: 2008 A Management System for Energy, which in 2000 adopted as the state standard (supplemented in 2008) [4].

The Energy Management Automated System (EMAS) includes the next subsystems [4]:

- Integrated Automated Recourse Planning (IARP);

- Energy Audit Subsystem (EAS);

- Energy Efficiency (EE) and Demand Side Management (DSM);

- Supply-Side Planning Subsystem (SSP);

- Automated Monitoring and Targeting (AM\&T);

- Energy Scheduling Management (ESM);

- End Users Consumption Management (ECM);

- Data and Results Energy Recourse Planning Verification (D\&RV)

\section{Aim of the research}

The aim of the below research is to describe the mathematical provision of the computer aided system of industrial enterprises energy monitoring to increase the efficiency of investment planning in modernizing energyconsuming production processes, improving the competitiveness of these enterprises and reducing energy costs.

\section{Analysis of recent research and publication}

In modern methods of analyzing the energy efficiency of industrial enterprises, the concept of benchmarking of energy efficiency has been developed [5]. This concept is to spread best practices and best achievements of machinebuilding enterprises.

Literary sources $[5,6,7,8]$ use several indicators of industrial energy efficiency. Moreover, for the comparison of different types of energy resources and their total accounting of its reserves, the unit of accounting of the "conventional fuel" is adopted, the heat of combustion is $29,3 \mathrm{MJ} / \mathrm{kg}(7000 \mathrm{kcal} / \mathrm{kg})$.

1. The energetic level of production $\left(E_{L P}\right)$ is characterized by the ratio of the total production cost $(P)$ to the total cost of energy consumed $(V)$ :

$$
E_{L P}=\frac{P}{V}
$$

2. Specific energy content of products $(\omega)$ characterizes the consumption of energy resources and heat carriers in the production unit:

$$
\omega=\frac{V}{N},
$$

where $V$ is the annual volume energy (electric power, thermal energy, various types of fuel, etc.) consumed for the production, which reduce through the theoretical equivalents to single unit of measurement; $N$ is the annual output program. 
3. Integral coefficient of efficiency all types of consumed energy $\left(K_{u}\right)$ :

$$
K_{U}=\eta_{1} \cdot \eta_{2}
$$

where $\eta_{1}$ is the weighted-average efficiency coefficient of distribution and transformation of energy in the enterprise; $\eta_{2}$ is the weight-average efficiency coefficient of energy consuming equipment.

4. Loss of energy $(P)$ - the difference between the amounts of delivered $\left(E_{d e l}\right)$ and consumed $\left(E_{c o n}\right)$ energy:

$$
P=E_{d e l}-E_{c o n} \text {. }
$$

The analysis of energy efficiency indicators of enterprises has shown that any system of indicators is not perfect. That is, the system of indicators included in the energy efficiency assessment system for each enterprise needs to be clarified, taking into account the energy intensity of industrial products, the volume and spectrum of production, as well as the features of energy-consuming structural and technological processes that allow or rigidly regulate the use of alternative energy sources.

\section{Main material}

\subsection{System analysis of enterprises energy efficiency monitoring indicators}

The mathematical problem definition of industrial enterprises energy efficiency monitoring is a set of mathematical relationships that describe the behaviors and characteristics of the modeling object, such as: technological processes, potential energy resources and package of actions for machine-building energy efficiency increase. It is necessary to formalize the input data for monitoring, to create a database of production, auxiliary, administrative and household processes, to substantiate the classes and characteristics of potential energy resources, and formally describe the relations between them. This class of mathematical description can be attributed to deterministic models. For this class of enterprises energy efficiency monitoring objects, the structure of the model contains parameters that reflect their features, such as: the conformity of consumption of certain types of resources in specific energy-consuming processes related to the type of economic activity of the given enterprise, type (single, serial or mass) and the organizational form of production (flow or group production), the nomenclature and the annual output production of machined products. The search for these parameters values is carried out using parametric identification methods based on a passive experiment.

In accordance with the main goal of the research, 2 main stages are formulated for solving the problem of the machine-building enterprise energy use improvement:

1-st stage. Comprehensive analysis of the energy expenditure structure in dynamics (depending on the seasonality of works, the type and volume of production, the consumption of energy resources certain types and their attachment to specific production processes, etc.) (Subsystem of internal energy benchmarking).

2-nd stage. Development of the substantiated plan of actions for modernization of machine-building energyconsuming processes based on an optimization model (Subsystem of operational investment planning)

This article proposes the use of a methodology for analyzing the energy efficiency of production enterprise based on the calculation of the integral coefficient of energy resources effective use $(\mathrm{Ku})$, which is attributed to the total cost of production. In other words, the criterion for the effectiveness of the total energy costs of all types is their percentage relation to the total cost of production.

Coefficient $\mathrm{Ku}$ is calculated according to the formula:

$$
K_{u}=\frac{B_{\Sigma}}{S_{\Sigma}} \times 100 \%=\frac{\sum_{i=1}^{I} \sum_{j=1}^{J} B_{i j} \cdot k k_{i}}{\sum_{m=1}^{M} S_{m} \cdot N_{m} \cdot k b_{m}} \times 100 \% \rightarrow \min ,
$$

where $B_{\Sigma}$ is the volume of all types used energy resources consumption for the reporting period (year, month); $S_{\Sigma}-$ total annual cost of products for the reporting period; $i=\overline{1, I}$ is type of energy resources used in the enterprise; $j=\overline{1, \mathrm{~J}}$ is type of process or structure consuming different types of fuel and energy; $B_{i j}$ is the consumption of $i$-th energy in $j$-th energy process during the reporting period; $k k_{i}$ is the calorie equivalent of $i$-th energy resource, (Gcal), which is determined on the basis of documents on fuel supply; $m=\overline{1, \mathrm{M}}$ is name of engineering product which 
produced on concrete machine-building enterprise; $N$ is the annual output program of $m$-th product; $S_{m}$ is the $m$-th product cost; $k b_{m}$ - coefficient of unrealized or defective $m$-th product.

Calculation of $i$-th type energy cost in the $j$-th energy consumed process for the reporting period $B_{i j}$ can be implemented by the formula:

$$
B_{i j}=V_{i} \cdot Q_{i j},
$$

where $V_{i}$ is the average annual cost of the unit of measurement (ton, $\mathrm{kW}, \mathrm{m}^{3}$ ) of the $i$-th energy resource (electricity, gas, coal, etc.); $Q_{i j}$ is the volume of $i$-th type energy using in $j$-th energy process during the reporting period (determined by the results of energy audit of electricity, gas, heat energy or cost accounting documentation for the supply of certain types of fuel).

Machine-building energy-consuming processes are classified as:

1. Main production processes and constructions
a. Blank production $(\mathrm{j}=1)$;
b. Machining production $(\mathrm{j}=2)$;
c. Mechanical assembly production $(\mathrm{j}=3)$;
d. Testing and packaging production $(j=4)$

2. Auxiliary services, processes and constructions

a. Intra-factory transport processes and garages $(j=5)$;

b. Warehouses and warehousing processes $(j=6)$.

3. Administrative services and constructions
a. Administrative and administrative buildings $(j=7)$
b. Buildings for design and technological personnel $(j=8)$
c. Buildings for enterprise security guard $(j=9)$

4. Personal service buildings (locker rooms, dining rooms, etc.) $(j=10)$

Achievement of great energy saving is possible only if a quality energy audit is to be carried out, for which should be involved an energy service company interested in obtaining reliable results of the enterprise state, including minimizing the measurement errors.

Thus, the initial data of the automated benchmarking system for the machine-building enterprises are the following indicators:

1. Assortment of products $(m=\overline{1, M})$.

2. Cost of $m$-th products $\left(S_{m}\right)$.

3. The percentage of unrealized or defective $m$-th name products $\left(k b_{m}\right)$.

4. Availability of own power generating unit (boiler house, generator substation, etc.) or dependence on external power supply enterprises.

5. The structure of the production enterprise (production, support, administrative and household buildings and premises).

6. Types of energy resources used in the enterprise $(i=\overline{1, I})$.

7. Types of energy processes that make up target fuel and energy consumption $j=\overline{1, \mathrm{~J}}$.

8. Audit results of $i$-th energy resource in $j$-th energy process energy use $\left(Q_{i j}\right)$.

The reference information for the automated benchmarking system is based on the data obtained as a result of the analysis of the energy resource information database (state, regional prices and purchase prices of certain types energy resources) - $V_{i}$, as well as standard calorie equivalents of different energy resources types. Calculated unit of energy resources is proposed for the efficiency analysis comparison of the different types of fuel energy properties. As a unit for this value, a fuel with a heat of combustion of $29.3 \mathrm{MJ} / \mathrm{kg}$ or $7000 \mathrm{kcal} / \mathrm{kg}$ is accepted. For gaseous energy resources, the heat of combustion is taken as one unit of volume.

The second stage of the main goal realization is to develop a plan for modernization of the machine-building energy-consuming processes (Subsystem of Operational Investment Planning). The method of solving this problem is as follows:

1. Classification of alternative actions that will reduce the specific energy consumption of machine-building production.

2. Establishing indicators for the effectiveness of the implementation of each action and its value. 
3. Ranking actions by efficiency indicator.

4. Development of an alternative plan for energy efficiency actions taking into account the permissible value of investment capital.

5. Optimization and correction of the improvement energy efficiency plan for machine-building enterprise.

Let's describe alternative energy saving actions, as $Z_{x y j}$, where $x=\overline{1, X}$ is the classification number of the action (set $x=1$ - for actions to improve the energy consumption of production processes; $x=2$ - for actions of constructions and engineering systems modernization; $x=3$ - for organizational actions of energy resource economy); $y=\overline{1, Y}$ is the classification number of the event (Table 1); $j=\overline{1, \mathrm{~J}}$ is the type of energy-consuming process for which this action will be implemented. For example, the action with the classification mark $Z_{213}$ involves carrying out construction works $(\mathrm{x}=$ 2) for thermal insulation $(y=1)$ of the shop of mechanical assembly production building $(j=3)$.

Table 1. Classification of actions intended to reduce the specific energy machine-building enterprise consumption

\begin{tabular}{|c|c|c|}
\hline Name of action $Z_{x y j}$ & $\begin{array}{l}\text { Classification mark } \\
\text { of action }(x)\end{array}$ & Number of action $(y)$ \\
\hline Change of the technological process structure and parameters & \multirow[t]{5}{*}{1} & 1 \\
\hline $\begin{array}{l}\text { Modernization of technological equipment or transport and warehouse } \\
\text { systems }\end{array}$ & & 2 \\
\hline Automation and mechanization of production and transport processes & & 3 \\
\hline Changing the nomenclature and product output program & & 4 \\
\hline Optimization of operational-calendar planning of the enterprise's work & & 5 \\
\hline $\begin{array}{l}\text { Construction and installation work to improve the thermal insulation of } \\
\text { buildings and structures of the enterprise }\end{array}$ & \multirow[t]{4}{*}{2} & 1 \\
\hline $\begin{array}{l}\text { Construction and installation works on the reconstruction of engineering } \\
\text { systems }\end{array}$ & & 2 \\
\hline $\begin{array}{l}\text { Construction or modernization of own power generating unit (boiler } \\
\text { houses, equipment for generation of alternative energy sources) }\end{array}$ & & 3 \\
\hline Changing the energy resources & & 4 \\
\hline Installation of additional energy meters & 3 & 1 \\
\hline Implementation of automated energy management system & \multirow[t]{2}{*}{3} & 2 \\
\hline Implementation of incentive measures to ensure energy efficiency & & 3 \\
\hline
\end{tabular}

Each such action is characterized by a tuple of parameters $Z_{x y j}=\left\langle S_{x y j} ; F_{x y j}\right\rangle$, where $S_{x y j}$ - the carrying value of costs associated with the implementation of the $Z_{x y j}$-th action for $j$-th production process; $F_{x y j}$ - the index of energy economy efficiency for $Z_{x y j}$-th action.

This coefficient $F_{x y j}$ is a conditional indicator that formally assesses the effectiveness of each $Z_{x y j}$ th action implementation, as the ratio of the energy cost savings $\Delta B_{x y j}$ to the total cost of installation works and materials associated with the implementation of this action:

$$
F_{x y j}=\frac{\Delta B_{x y j}}{S_{x y j}}
$$

where $\Delta B_{x y j}$ is the difference between the annual cost of all types of energy consuming in $j$-th process in case before and after the implementation of this $Z_{x y j}$ th energy efficiency action.

For example, if for building construction works on thermal insulation of the mechanical assembly shop (the action with classification mark $Z_{213}$ ) it is necessary to raise $S_{213}=2$ million $\mathrm{UAH}$, but with this the economy of the thermal energy use in the cold period will be $\Delta B_{213}=450$ thousand UAH (according to the audit of similar enterprises), then the efficiency factor can be calculated as:

$$
F_{213}=\frac{\Delta B_{213}}{S_{213}}=\frac{450000}{2000000}=0,22 .
$$

An algorithm for deciding on optimal planning of actions to increase machine-building enterprise energy efficiency, which based on an internal benchmarking analysis, will be described below. 


\subsection{Algorithm of the computer aided system for monitoring and optimal planning of actions to increase machine-building enterprise energy efficiency}

In accordance with the foregoing model, the total generalized algorithm of the computer aided subsystem of energy consuming processes benchmarking (1-st stage) and subsystem of optimal planning of actions to increase machine-building enterprise energy efficiency(2-nd stage) is developed (Fig.1).

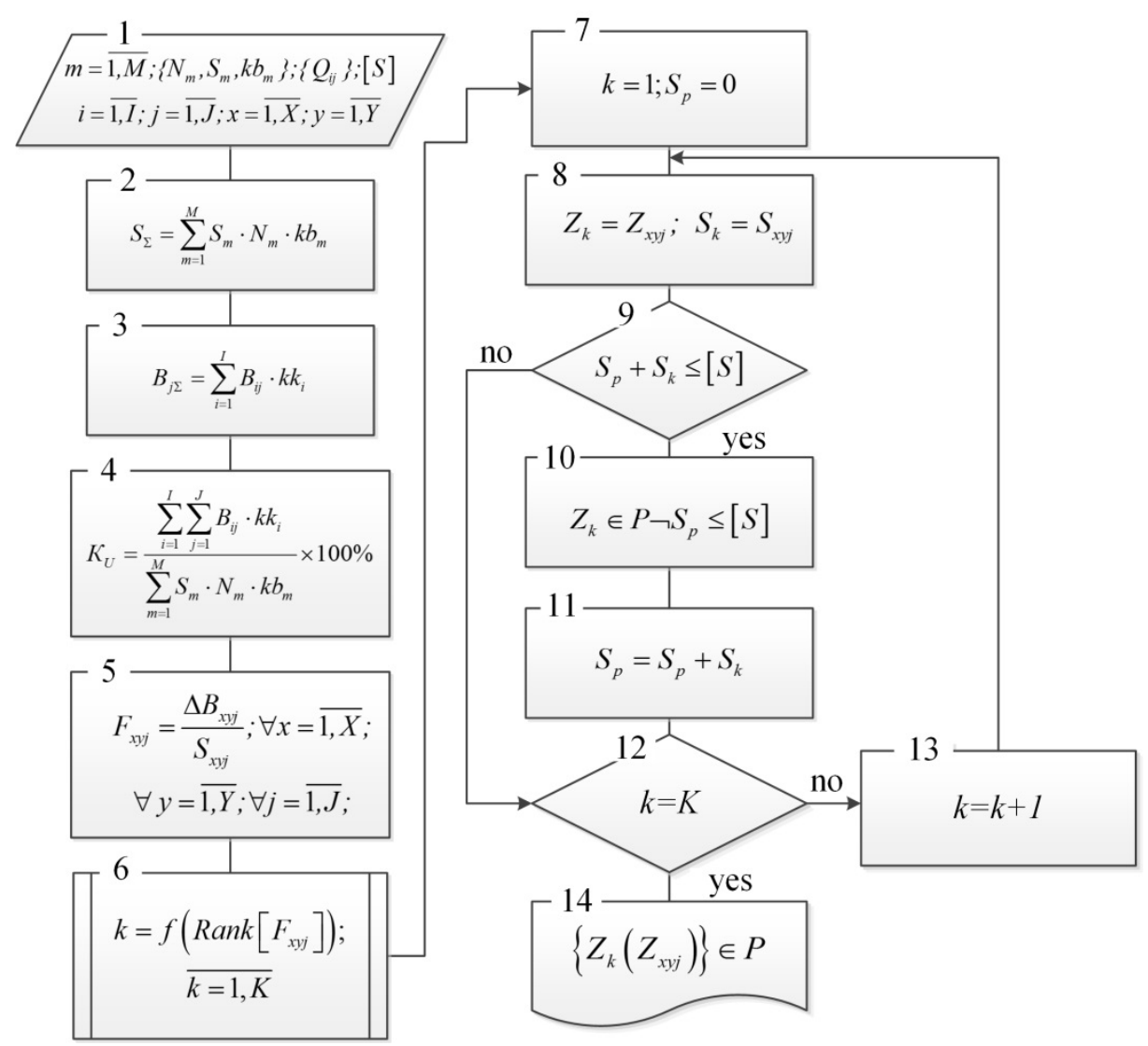

Fig.1. Flow chart for generalized algorithm of the monitoring and planning of actions to increase machine-building enterprise energy efficiency

The algorithm can be conventionally separated into the following steps:

- $\quad$ interactive task of initial data (block 1 (Fig.1);

- calculation of the energy component of expenditures by types of energy consuming processes and types of energy resources (blocks 2-3);

- calculation of the integral coefficient of energy resources effective use $\left(K_{u}\right)$, which is attributed to the total cost of this enterprise production (block 4);

- ranking of alternative actions for the modernization of energy-consuming processes based on the indicator of the effectiveness of these measures (blocks 5-6);

- analysis of the implementation of the conditions for cost limiting the alternative actions to increasing energy efficiency of the enterprise (blocks 7-11);

- formation and correction of the action's plan for modernization of machine-building enterprise energyconsuming processes and buildings (block 14).

The initial data for the computer aided subsystem of energy consuming processes benchmarking (1-st stage) are the names of engineering products $m=\overline{1, \mathrm{M}}$, the annual output program $\mathrm{N}_{m}$ of products and their total cost $S_{m}$, the types of energy resources $i=\overline{1, I}$ used in the enterprise, types of production processes consuming $j=\overline{1, \mathrm{~J}}$ different types of fuel and energy, and results of energy audit - the costs of all types of energy resources in the relevant production shops of 
this enterprise $\left\{Q_{i j}\right\}$. The initial data for the computer aided subsystem of optimal planning of actions $Z_{x y j}$ to increase machine-building enterprise energy efficiency (2-nd stage) are the nomenclature of the alternative actions listed in Table 1 based on classification type $x=\overline{1, X}$, classification code $\mathrm{y}=\overline{1, Y}$ and the limit value of total annual expenditures appropriated for the modernization of energy-consuming processes and shop's constructions $[S]$.

First, the cost of the annual output program of m-type products $S_{m \Sigma}$ is calculated, taking into account the coefficient of unrealized or defective products $\left(k_{b m}\right)$. The total cost of the program of release $S_{\Sigma}$ is determined by all types of the enterprise products (block 2). Calculation of the cost of $i$-th type energy in $j$-th type energy process $\left(B_{i j}\right)$ is calculated taking into account the consuming volume of $i$-th type energy for $j$-th type energy process realization $\left(Q_{i j}\right)$ and the current cost of the unit of measurement of $i$-th energy resource $\left(V_{i}\right)$. Total energy costs in $j$-th energy consumption process $B_{j \Sigma}$ take into account regulatory calorie equivalents for all types of energy resources $k k_{i}$ (block 3).

The main criterion of the energy consuming efficiency for the concrete machine-building enterprise is the integral coefficient of energy resources real use $\left(K_{u}\right)$, taking into account their caloric equivalents and different types energy costs, which is divided to the total cost of production (block 4).

For each investment alternative actions to improve energy efficiency, the efficiency of such $Z_{x y j}$-type measure $F_{x y j}$, as the ratio of the amount of energy savings $\Delta B_{x y j}$ to the costs of works and materials $S_{x y j}$, associated with the implementation of this measure in accordance with the formula (7) is calculated (block 5).

The next stage of the system's operation is a subprogram of ranking all alternative actions $\left\{Z_{x y j}\right\}$ on the condition of decreasing the efficiency indicator $F_{x y j}$. That is, an ordered list of energy saving measures is created, in which the serial number of the action $k=\overline{1, K}$ is selected, based on the condition of the indicator reduction $F_{x y j}: k=f\left(\operatorname{Rank}\left[F_{x y j}\right]\right)$ (block 6).

The logical sequence procedure for the development of an energy efficiency improvement plan $\left\{Z_{x y j}\right\} \in P$ is implemented as follows:

1. First, the most effective energy saving action is assigned number $1(k=1)$ and this measure is conditionally included into the action plan (block 7). The preliminary cost value $S_{p}$ is assumed to be $0\left(S_{p}=0\right)$.

2. Verification is made to determine if that the cost of this measure $S_{k}$ does not exceed the allowable costs $[S]$. In the positive case of the implementation of the condition $S_{k} \leq[S]$ (block 9), we proceed to step 3. Otherwise, this action $S_{k}$ is ignored; we proceed to the next action $Z_{k+1}$ and repeat the verification of this step.

3. We finally incorporate the action into the action plan $\left\{Z_{k}\right\} \in P$ (block 10), we change the current expenditure value as $S_{p}=S_{p}+S_{k}$ (block 11) and proceed to consideration of the next action name $k=k+1$ (block 13).

4. The iterative procedure for forming a plan for energy conservation measures is carried out until the full list of the action plan is exhausted $(k=K)$ (condition - block 12).

Thus, after verifying the expediency and the possibility of including each of the actions in the determined plan, this list is confirmed by the manager of the company and is subject to implementation.

Interpreted high-level general-purpose programming language Python, including the graphical interface development module and the high-level open Python framework Django is used to implement the software of the machine-building enterprises energy saving project. The developed system is a classic example of the implementation of EMAS (Energy Management Automated System) energy management systems and will have an impact on Integrated Automated Recourse Planning Integrated Energy Planning (IARP), Supply Sided Energy Planning (SSEP) and Operational-Calendar Process Management Energy Consumption ESM (Energy Scheduling Management).

\section{Conclusion}

1. Development of the monitoring system and systemic planning of actions to ensure machine-building enterprises energy efficiency in Ukraine is topical, since in order to increase the competitiveness of domestic engineered products, it is necessary to substantially reduce the energy component of the manufacture cost, which is several times higher than that energy components of total cost in the developed industrial countries. 
2. Two main parts for the implementation of the computer-aided system to increase machine-building enterprise energy efficiency are proposed:

- Subsystem of internal energy benchmarking makes comprehensive analysis of the energy expenditure structure in dynamics (depending on the seasonality of works, the type and volume of production, the consumption of energy resources of certain types and their attachment to specific production processes, etc.).

- Subsystem of operational investment planning fulfills development of the substantiated plan of actions for modernization of machine-building energy consuming processes based on proposed optimization models.

3. The methodology of energy efficiency analysis of a machine-building enterprise, based on the calculation of the integral factor of utility $\left(K_{U}\right)$ of energy resources and energy costs is proposed.

4. The iterative stage of the action plan development to ensure the energy efficiency of an enterprise, taking into account the permissible value of investment capital, is estimated by the total coefficient of every such measure implementation efficiency, which is determined by the ratio of the energy consumption cost reduction to the cost of installation works and materials associated with the implementation of these actions.

\title{
References
}

[1] On Approval of the Action Plan for the Implementation of the "Energy Sector Reform (2020)" Energy Strategy of Ukraine until 2035 "Safety, Energy Efficiency, Competitiveness". (2018) Order of the Cabinet of Ministers of Ukraine dated June 6, 2018 No. 497-p. https://zakon.rada.gov.ua/laws/show/497-2018. (in Ukrainian)

[2] Review of Analytical Work of International Energy Organizations on the State and Scenarios of the Development of the World Energy Sector with the Forecast of Investing in Energy Efficiency (2016). Scientific and Project Center for the Development of the United Energy System of Ukraine» National Energy Company «Ukrenergo». (in Ukrainian).

[3] Market Report Series: Energy Efficiency 2018. (2018) Analysis and Outlooks to 2040. https://webstore.iea.org/market-report-series-energyefficiency-2018.

[4] A Management System for Energy. American National Standard: ANSI/MSE 2000:2008. (2008) Publish by Georgia Tech Energy and Environmental Management Center (GTEEMC). https://webstore.ansi.org/standards/gteemc/ansimse20002008

[5] Leslie, P., Pearce, J., Harrap, R., Sylvie, D. (2012). The application of smartphone technology to economic and environmental analysis of building energy conservation strategies. International Journal of Sustainable Energy. 31 (5), 295-311. doi: $\underline{10.1080 / 1478646 X .2011 .578746 .}$

[6] Thumann, A., Niehus, T., Younger, W. J. (2012). Handbook of Energy Audits. 9-th Edition. CRC Press. London.

[7] Worrell, E., Bernstein, L., Joyashree, R., Price, L., Harnisch, J. (2009) Industrial energy efficiency and climate change mitigation. Energy Efficiency, 2, 109-123. doi 10.1007/s12053-008-9032-8.

[8] Valencia-Ochoa G., Cardenas Y., Ramos E., Morales A., Campo J. (2017) Energy saving in industrial process based on the equivalent production method to calculate energy performance indicators. Chemical Engineering Transactions, 57, 709-714. doi: 10.3303/cet1757119

\section{Автоматизована система моніторингу та планування заходів підвищення енергоефективності машинобудівного підприсмства}

\author{
Наталія Ступницька \\ Наиіональний університет «Львівська політехніка», вул. С. Бандери, 12, Львів, 79013, Украӥна
}

\begin{abstract}
Анотація
Описана математична модель аналізу ефективності енергетичних витрат машинобудівного підприємства (залежно від типу та обсягу продукції, обсягів споживання окремих видів енергоресурсів в умовах конкретних виробничих процесів тощо). Наведено методологію та математичну модель планування заходів щодо модернізації виробничих процесів промислового виробництва. Запропоновано здійснювати оцінку ефективності енергозберігаючих заходів шляхом розрахунку відношення зниження вартості енергоспоживання до вартості будівельно-монтажних робіт та матеріалів, пов'язаних з впровадженням цих заходів. Розглянуто проблемно-орієнтовану класифікацію енергоспоживчих виробничих процесів та альтернативних заходів, спрямованих на зменшення витрат паливно-енергетичних ресурсів машинобудівного виробництва. Запропоновано алгоритм та програмну реалізацію автоматизованої системи моніторингу та планування заходів з підвищення енергоефективності машинобудівних підприємств.
\end{abstract}

Ключові слова: математична модель; моніторинг енергоефективності; підприємство; енергозбереження. 